\title{
Optimalizace procesu generování map pomocí XML
}

\author{
Otakar Čerba \\ Oddělení geomatiky, Katedra matematiky, \\ Fakulta aplikovaných věd, Západočeská univerzita v Plzni \\ ota.cerba@seznam.cz
}

Klíčová slova: kartografické procesy, XML, Atlas mezinárodních vztahů, optimalizace

\begin{abstract}
Abstrakt
Př́spěvek je zaměrený na optimalizaci procesů použitých při tvorbě Atlasu mezinárodních vatahů [Wai2007]. Tento atlasový projekt vznikl v létech 2006-2007 na půdě Západočeské univerzity v Plzni. Jednotlivé mapy tohoto tištěného atlasu byly generovány metodami webové kartografie, přičemž šlo o prvni rozsáhlý projekt, kdy byly použity XML (eXtensible Markup Language) technologie pro generování tematických map ve formě klasického atlasu. Proto se během tvorby atlasu a po jejim ukončeni objevily nedostatky, které by měly být v případě dalšího využiváni vytvořených postupů odstraněny nebo alespoñ částečně eliminovány. Př́spěvek se skládá ze tři částí, které popisuji vytvořenou publikaci, princip generování map atlasu a navrhovaná zlepšení použivaných postupü.
\end{abstract}

\section{Úvod - Atlas mezinárodních vztahů}

Atlas mezinárodních vztahů [Wai2007] je publikace, která byla vytvořena desetičlenným autorským kolektivem pod vedením PhDr. Śárky Waisové, PhD. Součástí autorského kolektivu byli zástupci Katedry politologie a mezinárodních vztahů Filosofické fakulty Západočeské univerzity v Plzni (ZČU), kteří zajištovali textovou část a sběr dat. Tvorba kartografických výstupů byla úkolem členů oddělení geomatiky, které spadá pod Katedru matematiky Fakulty aplikovaných věd ZČU. Tvorbu kartografické části zajištovali Ing. Magdaléna Baranová, Doc. Ing. Václav Čada, CSc., Ing. et Mgr. Otakar Čerba a Ing. Karel Jedlička. Důvodem vzniku atlasu byla především absence podobné publikace na českém trhu. Atlas by mohl být využívaný širokým spektrem odborníků z nejrůznějších oborů (politologie, politická geografie, studium mezinárodních vztahů, zahraniční obchod apod.) a studenty příslušných vědních na univerzitách i na středních školách. Své místo by tato publikace mohla nalézt i v knihovnách laikư, především v souvislosti s rasantními změnami, které na politické mapě světa odehrávají a také se stále rostoucím významem politiky a globálních vztahů v životě běžného člověka. 
Finální verze atlasu obsahuje 72 map (viz následující tabulka) a doprovodných textů na více než 150 stránkách. Atlas je dále doplněn dalšími obrázky, tabulkami a grafy [Čer2007a], [Bar2007].

\begin{tabular}{|lc|}
\hline Druh map & Počet map \\
\hline Politická mapa světa & 1 \\
\hline Fyzicko-geografická mapa světa & 1 \\
\hline Tematické mapy & 47 \\
\hline Atypické mapy & 4 \\
\hline Mapy politicko-geografických regionů & 4 \\
\hline Detailní mapy & 15 \\
\hline Celkem & 72 \\
\hline
\end{tabular}

Table 1 - Struktura Atlasu mezinárodních vztahů

\section{Princip generování map}

Kromě obsahu, grafické úpravy a rozměrů byl základním limitním faktorem pro tvorbu tematických map Atlasu mezinárodních vztahů výstupní formát. Veškeré kartografické výstupy bylo potřeba vytvořit ve formátu PDF (Portable Document Format), který požadovala tiskárna vydavatelství Aleš Čeněk.

Postup tvorby map:

1. Navržení základního rámce map (měřítková řada, grafický design, umístění a tvar základních kompozičních prvků apod.; více viz [Čer2007a]).

2. Volba kartografického zobrazení (autorský kolektiv vybral modifikované vyrovnávací zobrazení Times; více viz [Bar2007]).

3. Volba interpretačních metod (viz Tab 2 [Čer2007a], [Bar2007]).

4. Generování map.

5. Kontrolní a validační procedury.

Ačkoli finálním produktem měla být tištěná verze atlasu, jednotlivé mapy byly generovány technikami webové kartografie. Hlavním důvodem byla především předpokládaná aktualizace map, kterou si bezpochyby vyžádá překotný vývoj na poli mezinárodních vztahů. Vytvořené šablony je možné využívat i pro další zpracování prostorových dat. Výstupem námi použité metody byly mapy ve formátu SVG (Scalable Vector Graphics), které byly pomocí programů Inkscape (grafická editace a transformace do formátu Postscript) a GSVIEW32.EXE, A Ghostscript graphical interface převedeny do formátu PDF určeného pro výsledný tisk.

Pro generování map byly použity formáty založené na bázi značkovacího jazyka XML (eXtensible Markup Language) a prŕbuzné technologie. Konkrétně se jednalo o formáty ([Čer2007a], [Bar2007]):

1. Vlastní XML schéma (soubor _atlas.xml) popisující jednotlivé mapy atlasu, mapové 
symboly, barevné stupnice (barevné stupnice většinou pochází z webových stránek Cynthie A. Brewer ${ }^{1}$ ) a formáty výsledných map.

2. XML Namespaces (jmenné prostory) umožňující používat v jednom dokumentu více typů značení neboli více značek (tagů) pro elementy a atributy. Např́íklad dokument _atlas.xml obsahuje elementy definované ve vlastním značení a také prvky ze schématu SVG. Podobně i transformační styl se skládá z prvků jazyků XSLT, XLink a SVG.

3. JML neboli JUMP GML (Geography Markup Language) představující specifickou podmnožinu jazyka GML, který je primárně určený pro popis geografických dat. Formát JML sloužil ke kódování geoprostorových i atributových dat.

4. XSLT (eXtensible Stylesheet Language Transformation), který je součástí komplexního stylového a transformačního jazyka XSL (eXtensible Stylesheet Language). XSLT se používá pro transformaci XML do jiných, nejen XML formátů. Transformační styl slouží k převodu datových souboru (formáty JML a XML) na vlastní mapu (formát SVG). Pro tvorbu atlasu byly nejprve používány šablony (soubor_atlas.xsl) zapsané v kombinaci první verze jazyka XSLT a jejího rozšíření EXSLT. V červnu 2006 došlo k přepsání šablon nové verze XSLT 2.0.

5. XPath (XML Path Language) představuje dotazovací jazyk určený pro výběr jednotlivých částí XML dokumentu. Při tvorbě atlasu byl jazyk XPath používaný pro výběr jednotlivých částí mapy (např. zeměpisná sít, popisky, diagramy apod.), které byly následně zpracovávány transformačním procesorem podle zásad transformačního stylu. $\mathrm{V}$ průběhu tvorby atlasu došlo podobně jako v př́padě XSLT ke změně verze XPath nyní je v souboru _atlas.xsl používán XPath 2.0.

6. XLink (XML Linking Language) umožňuje odkazy mezi XML dokumenty i mezi jeho částmi. Oproti odkazům známým z HTML umožňuje i dvousměrné nebo dokonce vícesměrné odkazy. $\mathrm{V}$ jednotlivých mapách se XLink 1.0 používá pro odkazy na prríslušné barevné přechody, přičemž původně měl sloužit také $\mathrm{k}$ vytvoření vazeb mezi popisem symbolu a jeho lokalizací.

7. SVG (Scalable Vector Graphics) je otevřený vektorový formát určený především pro popis a distribuci dvourozměrných vektorových dat v prostředí internetu (více viz [Čer2006b]). Mapy byly generovány ve formátu SVG 1.1.

8. XHTML (eXtensible HyperText Markup Language) je jazyk určený pro popis obsahu www stránek. Jedná se o přímého následníka velice populárního jazyka HTML (HyperText Markup Language), resp. o propojení HTML a XML. V projektu Atlas mezinárodních vztahů se jazyk XHTML 1.0 Strict společně s kaskádovými styly použil pro definování webových stránek s jednotlivými mapami, které sloužily pro jejich prohlížení a př́padné revize.

9. CSS (Cascading StyleSheet, kaskádové styly) je jednoduchý stylový jazyk užívaný především ve spojení s HTML k definování vizualizačních pravidel. V našem případě kaskádové styly (verze 2.1) posloužily jednak pro popis vizualizačních pravidel pro webovou stránku s ukázkami map a především pro určení vizualizačních pravidel jednotlivých map. $\mathrm{K}$

\footnotetext{
${ }^{1}$ http://www .personal .psu.edu/cab38/ColorBrewer/ColorBrewer_intro.html
} 
mapám jsou kaskádové styly připojeny dvěma způsoby - společné vizualizační vlastnosti jsou k mapám připojeny pomocí externího stylu (zakladni_styl.css) a některé specifické vlastnosti jsou popsány pomocí inline stylů a XML prezentačních atributů - oba způsoby jsou zapsány jako atributy př́ślušných elementů.

Vlastní generování map probíhalo na principu přiřazení vizualizačního stylu jednotlivým datovým souborů. Příslušný styl a vstupní data byly zpracovány pomocí XSLT procesoru - v př́padě Atlasu mezinárodních vztahů byl použitý volně šiřitelný produkt Saxon 8.8 verze B, který implementuje jazyky XSLT 2.0, XPath 2.0 (starší verze XSLT a XPath jsou také podporovány), XQuery 1.0 a XML Schema 1.0. Více o generování map prostřednictvím XSLT stylů viz [Ten2003], [Čer2006a], [Čer2007b].

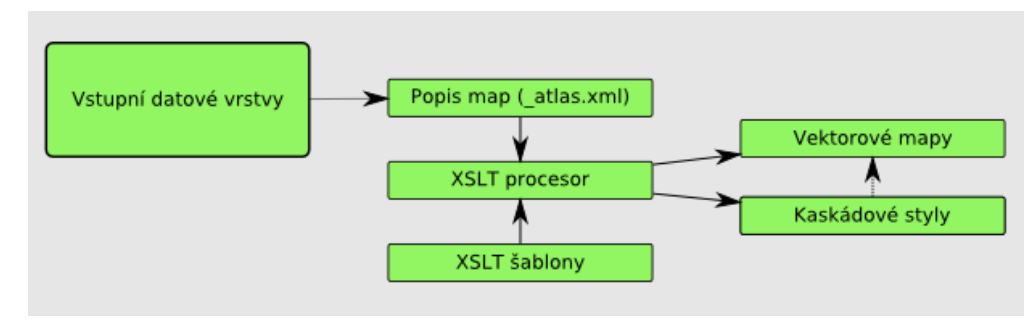

\section{Optimalizace procesu generování map}

Zvolený postup - generování map ve formátu XML z XML dat pomocí stylů zapsaných v XML s sebou přináší následující výhody [Bar2007]:

- Aplikace je sestavena výhradně z nekomerčního software. Uživatel může téměř všechny finanční prostředky použít na nákup kvalitních datových sad.

- S XML soubory lze pracovat bez ohledu na používané technologie, operační systém nebo softwarové vybavení. Uživatelé XML mají k dispozici velké množství nejruoznějšśího software - editory, parsery (programy pro kontrolu XML syntaxe), validátory, prohlížeče, XSLT procesory (prostředky pro práci se stylovými jazyky), konvertory a další. Velký podíl mezi XML software mají programy šířené pomocí nějaké otevřené licence.

- XML je velice rozšsiŕrenou technologií - na internetu se nachází obrovské množství informací ve formě článků, příspěvků z odborných konferencí, tutoriáli̊, mailových konferencí apod. Např́íklad téměř jedna čtvrtina všech příspěvků na konferenci SVG Open 2005 v nizozemském Eshende byla věnována geografickým informačním technologiím, především tvorbě map.

- Pomocí stylových a transformačních jazyků dochází k oddělení obsahu dokumentu od vizualizačních pravidel. Proto lze XML dokumenty velice snadno přizpůsobovat konkrétním potřebám uživatele. Na druhou stranu používání stylů s sebou přináší jednotný vzhled všech dokumentů s možností jednoduché a především rychlé aktualizace.

- Za celou aplikací stojí pouze jediná technologie. Navíc technologie, která se velice rychle vyvíjí, ale je podporovaná (v různé míře) většinou světových výrobců software.

Při vlastní tvorbě map docházelo k řadě chyb, které byly způsobeny především nezkušeností s projekty obdobného rozsahu a tématického zaměření (za upozornění na chyby a postřehy v 
průběhu tvorby map i po vydání publikace je zapotřebí poděkovat celému autorskému kolektivu, dále především Ing. Jánu Pravdovi, DrSc. a také Prof. RNDr. Vítu Voženílekovi, CSc., Doc. RNDr. Jaromíru Kaňokovi, CSc. a Mgr. Monice Čechurové, PhD.). Navrhované změny, které částečně eliminují zjištěné nedostatky, můžeme rozdělit do pěti základních skupin:

1. Popis generovaných map.

2. Optimalizace vstupních dat.

3. Optimalizace transformačních šablon.

4. Odstranění kartografických nedostatků.

5. Zlepšení datového a komunikačního toku.

\section{Popis generovaných map}

V současné době prudce narůstá počet geoprostorových dat, včetně kartografických výstupů. Proto je nutné vytvářet podrobné a standardizované popisy veškerých datových souborů. Tentýž problém řeší také směrnice INSPIRE (INfrastructure for SPatial InfoRmation in Europe), jejímž jedním úkolem je prosazení používání metadat. Metadatový popis je důležitý nejen z legislativního hlediska, ale také z pohledu sémantického webu, kdy metadatové záznamy umožní efektivnější vyhledávání a používání nejrůznějších katalogových služeb.

Pro př́pad vytvoření elektronické verze atlasu nebo aktualizací tištěné verze atlasu v digitální formě bude nutné doplnit generované mapy metadatovými záznamy. Obsah metadat by se měl řídit mezinárodní normou ISO 19115 a směrnicí INSPIRE. Z hlediska formátu je důležitá jeho otevřenost a standardizace - jako nejvhodnější se jeví formát na bázi XML DCMI (Dublin Core Metadata Initiative). Zařazení XML metadatového formátu umožní generování některých metadatových záznamů pomocí XSLT přímo z popisu map (např. název mapy). Další možností je vložení metadatových záznamů ve formátu DCMI přímo do popisu mapy (soubor _atlas.xml) pomocí XML Namespaces.

Metadatový popis by měl být připojen nejen k jednotlivým mapám, ale také k vytvořeným šablonám, popisným souborům, schématům, stylům nebo webovým stránkám, které jsou nedílnou součástí celého projektu.

\section{Optimalizace vstupních dat}

Vstupní datové vrstvy byly převzaty z datových sad distribuovaných společností ESRI. Data obsahovala drobné chyby z hlediska obsahu, například Španělsko prriřazené do Afriky nebo chybějící zakreslení státu Vatikán. Vzhledem ke stáří dat bylo zapotřebí také doplnění nového státního celku - Východní Timor, a změn atributů u některých zemí (např́ílad přejmenování státu Zair na Kongo).

Vzhledem k rozsahu dat a redundantní podrobnosti by bylo vhodné před vlastním zpracováním data generalizovat. Jedná se především o zjednodušení obrysů kontinentů (pro potřeby 
atlasu byla data velice podrobná) a spojení některých jednoduchých linií do řetězce linií. Jedinou formou generalizace aplikovanou na vstupní data bylo odstranění nadbytečných atributů (např. kódy měn apod.).

Další změnou, která byla nezbytná z pohledu procesu transformace dat do kartografického výstupu, bylo převedení původních dat z formátu Shapefile do formátu JUMP GML. Tato změna znamenala nárůst objemu dat o více než $400 \%$.

Mezi vstupní data se také zdrojový dokument _atlas.xml, který obsahuje popis jednotlivých map a dalších použitých nástrojů, například kartografických barevných stupnic. Základním vylepšením tohoto souboru je vytvoření schématu, které bude popisovat jednotlivé prvky dokumentu, jejich vzájemné vazby a případná omezení nebo tzv. „business rules“. Schéma by mělo sloužit také ke kontrole a validaci zdrojového souboru a zároveň by mělo zajistit přenositelnost tohoto základního stavebního prvku aplikace do jiných projektio a př́padná rozšsiřrení. Tento schémový soubor by mohl být součástí širšího schématu jazyka popisující mapy a jiné kartografické produkty. Součástí schématu by mohly být vazby na již existující XML deriváty zabývající se geografickými daty (metadatový popis, jazyk definují diagramové prvky mapy apod.). Jako v současnosti nejvhodnější schémový jazyk se jeví RELAX NG doplněný o datové typy používané v jazyku W3C XML Schema a některé konstrukce jazyka Schematron.

\section{Optimalizace transformačních šablon}

Další vylepšení se týká také transformačních šablon, které sloužily k převádění vstupních souborů prostorových dat na digitální mapy publikované v Atlasu mezinárodních vztahů. Optimalizace šablon spočívá jednak ve zkrácení kódu (odstranění nadbytečných prvků, modularizace, sestavování jednotlivých interpretačních kartografických metod jako sekvenci základních modulů) a také v implementaci všech nových prvků jazyků XSLT 2.0 a XPath 2.0. Z pohledu aplikace transformačních a dotazovacích jazyků založených na bázi XML do kartografie jsou důležité zejména následující vlastnosti obou výše uvedených jazyků:

- Pro digitální kartografii (především pro generování map) je výhodná práce sekvencemi a textovými řetězci, které mohou představovat seznamy souřadnic (např. ve formátu GML nebo SVG). Otázkou je rychlost transformačních procesorů, které jsou většinou napsány v Javě, při zpracování takového objemu dat, který je v oblasti geoinformačních technologií běžný.

- Prohledávání a rozřazování rozsáhlých dokumentů obsahující prostorová data s velkým počtem atributů zjednoduší a zřejmě také zrychlí používání klíču a možnost seskupování dat na základě zadaného výrazu (velice jednoduše se budou např́iklad raadit obce na základě příslušnosti k obci s rozšsiřrenou působností).

- XSLT 2.0 integrovala řadu funkcí EXSLT, které jsou při tvorbě digitálních map nezbytné. Např́klad se jedná o matematické funkce (součet, průměr, maximum, minimum) používané při tvorbě grafů a diagramů při generování kartodiagramů nebo při generování intervalů stupnic při generování kartogramů.

- Práce s datovými typy XML Schema, které jsou přebírány i do dalších aplikací (např. jazyky RELAX NG, OWL) je důležitá z hlediska tvorby obecného sémantického doku- 
mentu a také snažší kontrole správnosti dokumentu (zabrání se tak například používaní textových řetězů místo čísel apod.).

- Práce s regulárními výrazy patří mezi další výhody druhé verze XSLT. Například v SVG souborech půjde odstranit vysoké hodnoty jednotlivých souřadnic (dojde ke zmenšení velikosti souborů), „odříznutá“ hodnota bude do souboru vrácena pouze jednou ve formě translační transformace.

- XSLT zásadně změnilo charakter. Od stylového jazyku (jakési dokonalejší verze kaskádových stylů) se posouvá spíše do oblasti programovacích jazyků, o čemž svědčí doplnění a zdokonalení práce s funkcemi, podmíněné výrazy apod. [Nič2005]

Vyšší úrovni optimalizace brání nízká úroveň implementace XSLT 2.0 a XPath 2.0 (stejný problém mají i jiné XML technologie jako například SVG) v různých nástrojích. Výjimku tvoří XSLT procesor Saxon používaný pro generování map atlasu.

V budoucnosti (v případě dalšího využívání transformačních stylů) by měly být do transformačního stylu doplněny další šablony pro generování dalších kartografických interpretačních metod (různé typy kartogramů nebo kartodiagramů) a pro analýzu dat (tvorba stupnic, grafy četnosti...). V souvislosti s rozšířením transformačního stylu bude dokument _atlas.xsl modularizován (rozdělen na několik menších vzájemně propojených souborů).

\section{Odstranění kartografických nedostatků}

Kartografické nedostatky se projevují především díky tzv. „autorské slepotě“, díky níž tvưrcům map uniknou některé dílčí nedostatky ve využívání kartografických interpretačních metod. V př́padě Atlasu mezinárodních vztahů se jedná o

- Volbu kartografického zobrazení, která byla determinována „geodetickým pohledem“ na zobrazovanou problematiku. Jinými slovy při volbě kartografického zobrazení byla důležitá minimalizace zkreslení a výsledná kompozice mapy před zvýrazněním oblastí, které jsou z pohledu mezinárodních vztahů potřebné (např. rovníková Afrika) - „geografický pohled".

- Různé velikosti písma použité na Politické mapě světa evokují různý význam popisovaných objektů (států).

- Otázky vyvolala také použitá terminologie. Vzhledem k poměru map a doprovodného textu by mohla být publikace označena nikoli jako atlas, ale spíše jako mapová encyklopedie.

\section{Zlepšení datového a komunikačního toku}

Zlepšení datového a komunikačního toku (např. Komunikace mezi členy autorského kolektivu, verzování jednotlivých fází, forma, způsob a četnost zálohování apod.) patří v současnosti mezi aktuální problémy kartografie. Činnost kartografa by měla spočívat v řízení a vedení celého atlasového projektu a také v korigování „autorské slepoty“ spolupracovníků (tvůrců dat, marketingových specialistů, designérů apod.). 
V našem konkrétním případě se ukázala jako velice problematická komunikace mezi jednotlivými členy rozsáhlého kolektivu autorů. Řešením by mohlo být například použití softwaru pro vedení projektů (pro př́klad uved'me produkt Microsoft Office Project 2007). V průběhu prací jsme se pokusili zavést alespoň online tvorbu a sdílení dokumentů (docs.google.com), což se však nakonec nesetkalo s patřičným ohlasem. Data byla předávána v různých formátech (často se jednalo o texty ve formátu DOC nebo tabulky ve formátu XLS), které nemohly být automaticky převáděny do formátu zpracovatelných prostřednictvím geoinformačních technologií.

V procesu generování map se vyskytují i další riziková místa, která ovšem nejdou eliminovat změnou pracovního postupu. Změnu musí vyvolat především výrobci podpưrného software. Mezi nejvýraznější nedostatky patří slabší podpora formátu SVG a rychlost zpracování velkého množství dat interpretačním jazykem Java.

V atlasu nejsou využity veškeré možnosti vektorového formátu SVG. SVG např́íklad umožňuje velice elegantní a jednoduché definovaní symbolů. Ty je možné zapsat pouze jednou a další použití těchto symbolů lze zajistit pomocí odkazů, který je zapsaný v jazyku XLink. U takového symbolu je možné nejen zadat souřadnice nového umístění, ale „novému” symbolu lze přidat „nové” atributy, např́ílad transformaci (SVG umožňuje používání změny měřítka, zkosení, posun a rotace) nebo jiný vizualizační styl. Bohužel ne každý software umožňuje regulérní předávání symbolů pomocí XLink odkazů (stejné typ odkazů ovšem funguje v př́padě barevných přechodů - gradientů). Proto bylo nutné veškeré symboly pomocí stylu a transformačního procesu do výsledné mapy kopírovat, čímž se zvláště v prrípadě složitých symbolů zvětšila velikost výsledného souboru. Slabší podporu ze strany výrobců software mají i další vlastnosti formátu SVG jako např́klad animace, vzorky, ořezové cesty nebo podpora multimédií.

Jedním z dalších problémů byla rychlost aplikací založených na interpretačním jazyku Java. V jazyce Java byly vytvořeny stěžejní aplikace používané pro zpracování map atlasu, jako např́iklad transformační procesor Saxon, GIS software pro zpracování dat OpenJUMP a grafický editor Inkscape - důvodem pro výběr těchto aplikací byly především multiplatformnost a otevřenost. Tyto aplikace velice obtížně a pomalu zpracovávaly rozsáhlá data (průměrný JML soubor - 14,5 MB, průměrný SVG soubor - 8,5 MB, průměrný PS soubor - $14 \mathrm{MB}$, výsledná mapa ve formátu PDF - 1,9 MB).

\section{Závěr}

V České republice byla kartografická atlasová tvorba v nedávné minulosti poměrně opomíjena. Tento př́íspěvek shrnuje zkušenosti získané během více než roční práce na Atlasu mezinárodních vztahů. Navrhovaná zlepšení lze rozdělit do dvou skupin:

1. Optimalizace týkající se použité technologie, která je svým způsobem specifická a navíc je stále ve vývoji.

2. Optimalizace standardních kartografických procesů (získávání, hodnocení a modifikace vstupních dat, kartografické postupy, metody a použité prvky).

3. Zkvalitnění komunikačních procesů v rámci autorského kolektivu. 
Používání webových technologií při tvorbě atlasů je velice zajímavou technologií, která odpovídá současným aktuálním trendům světové kartografie (ICA Research Agenda [Vir2007]). $\mathrm{Z}$ tohoto důvodu by mohly navrhované optimalizační procesy sloužit jako podklad pro další projekty podobného charakteru.

\section{Seznam použitých zdrojů}

1. [Bar2007] Baranová, M., Čada, V., Čerba, O. Kartografická část Atlasu mezinárodních vztahů. In Kartografické listy 15. Bratislava: Kartografická spoločnost’ Slovenskej republiky, Geografický ústav Slovenskej Akadémie vied, 2007, str. 5-12. ISBN 80-89060-10-8. ISSN 1336-5274.

2. [Čer2006a] Čerba, O. Cartographic e-documents \& SGML/XML. In International Symposium GIS. Ostrava 2006. Ostrava: Vysoká škola báňská - Technická univerzita, 2006. Dostupné z:

3. [Čer2006b] Čerba, O. SVG v kartografii [online]. In Geoinformatics FCE CTU 2006. Praha: 2006. ISSN 1802-2669. Dostupné z:

4. [Čer2007a] Čerba, O. Tvorba map pro Atlas mezinárodních vztahů. In 9. odborná konference doktorského studia Juniorstav 2007. Brno: 2007. ISBN 978-80-214-3337-3.

5. [Čer2007b] Čerba, O. XML Technologies for Cartographers. In XXIII International Cartographic Conference. Moskva : International Cartographic Association, 2007.

6. [Nič2005] Nič, M. XSLT 2.0 Tutorial [online]. 13.12.2005. Dostupné z:

7. [Ten2003] Tennakoon, W.T.M.S.B. Visualization of GML data using XSLT [online]. 2003. Dostupné z:

8. [Vir2007] Virrantaus, Kirsi, Fairbairn, David. ICA Research Agenda in Cartography and GI science [online]. In ICA News, Number 48, June 2007. International Cartographic Association, 2007. Dostupné z:

9. [Wai2007] Waisová, Š.; Baranová, M.; Čada, V.; Čerba, O.; Jedlička, K.; Šanc, D.; Weger, K.; Cabada, L.; Romancov, M. Atlas mezinárodních vztahů: prostor a politika po skončení studené války. 1. vyd. Plzeň: Aleš Čeněk, 2007. 158 s. ISBN 978-80-7380015-4. 
